\title{
RESEPSI GAUDIUM ET SPES OLEH GEREJA INDONESIA
}

\author{
Laurentius Sutadi
}

\begin{abstract}
:
The $50^{\text {th }}$ anniversary of The Second Vatican Council opening is an important moment to research the Catolic followers reception of Church teaching in The Second Vatican Council's documents. Focus of this research is the Church reception for Pastoral Constitution of Gaudium et Spes. The pastoral Constitution on the Church in the Modern World Gaudium et Spes is the longest and the most complex document produced by the Second Vatican Council. This document articulates the relationship between the church and the world. The Church reception for Gaudium et Spes can be detected from three points: the Church effort to teach, the Church understanding to this substance document, and various Church movement that implement Gaudium et Spes items teaching at the centre world.
\end{abstract}

\section{Kata-kata Kunci:}

Resepsi, Konsili, Gaudium et Spes, kerygma, Gereja, dunia.

\section{PENDAHULUAN}

\subsection{Latar Belakang}

Artikel ini diolah kembali dari bahan ceramah yang disampaikan pada sebuah acara untuk memperingati 50 tahun Pembukaan Konsili Vatikan II pada awal Agustus 2012 di Surabaya. Panitia meminta untuk membahas tema "Pandangan Konsili Vatikan II tentang Gereja di Dunia Dewasa Ini dan Penerapannya dalam Gereja Katolik Indonesia". Dari tema tersebut tersirat suatu harapan bahwa penulis meneliti tentang penerapan dokumen Konsili Vatikan II, khususnya Konstutusi Gaudium et Spes, dalam kehidupan Gereja Katolik Indonesia. Namun, penulis memilih untuk meneliti tentang resepsi atau penerimaan Gereja Katolik terhadap Konstitusi Pastoral Gaudium et Spes. Dasar dari perubahan tema ini adalah bahwa sehubungan dengan sebuah konsili teologi biasanya tidak menggunakan kata penerapan (Latin: applicatio) melainkan kata Latin receptio (istilah Inggrisnya reception) yang dapat diterjemahkan dalam Bahasa Indonesia dengan hal menerima, penerimaan, penyambutan. ${ }^{1}$ Penerapan tentu saja menjadi salah satu unsur dari resepsi.

Penulis menggunakan bahan yang disampaikan di Surabaya sebagai bahan untuk pertemuan tahunan para imam dan tokoh umat Keuskupan Ketapang pada awal tahun 2013. Pertemuan di Ketapang ini diselenggarakan dalam rangka merefleksikan Tahun Iman yang dicanangkan oleh Paus Benediktus yang pemilihan waktunya didasarkan di antaranya pada peringatan 50 tahun Pembukaan Konsili Vatikan II. Peringatan 50 tahun Pembukaan Konsili Vatikan II dan Tahun Iman merupakan kesempatan istimewa untuk meneliti resepsi Keuskupan-Keuskupan di Indonesia terhadap ajaran-ajaran Konsili Vatikan II. Mengingat sedemikian kaya dokumen Konsili Vatikan II dan luasnya wilayah Geografis Indonesia, penulis memfokuskan penelitian ini pada resepsi Gereja Indonesia terhadap Konstitusi Pastoral Gaudium et Spes yang terjadi dalam tahap kerygmatik atau pewartaan dan kehidupan praktis sebagai penghayatan terhadap pokok-pokok gagasan Gaudium et Spes. 
Resepsi terhadap Gaudium et Spes sangat penting bagi kehidupan Gereja Indonesia mengingat semangat Gaudium et Spes yang menekankan dialog dan pelayanan sangat relevan bagi kehidupan Gereja Indonesia yang hidup dalam konteks kemajemukan. Dialog dan pelayanan merupakan cara berada Gereja untuk mewartakan Kabar Gembira di tengah situasi sosial politik zaman ini. ${ }^{2}$ Dialog dan pelayanan merupakan penghadiran Gereja yang berwajah kasih persaudaraan dan kerendahan hati di tengah kehidupan dunia ini. Gereja adalah saudara dan pelayan bagi semua umat manusia.

\subsection{Rumusan Masalah}

Untuk mengukur resepsi Gereja Indonesia terhadap Gaudium et Spes, hal pertama yang perlu dipahami adalah pokok-pokok ajaran apa yang termuat dalam Gaudium et Spes? Paparan terhadap hal ini berguna untuk menemukan langkah-langkah Gereja seperti apa yang bisa dikategorikan sebagai bentuk-bentuk konkrit resepsi Gereja Indonesia terahadap Gaudium et Spes. Pada bagian kedua ini bisa dirumuskan dua masalah penting; yakni 1) langkah-langkah konkrit seperti apa yang dilakukan Gereja Indonesia untuk melaksanakan kerygma atau pewartaan Gaudium et Spes?; dan 2) praksis kehidupan Gereja seperti apa yang bisa dikategorikan sebagai bentuk respesi terhadap Gaudium et Spes?

Ada tiga hal penting untuk mengukur keberhasilan proses dan tahap-tahap resepsi terhadap Gaudium et Spes. Pertama adalah melihat dan menginverntarisasi usaha-usaha konkrit Gereja untuk memperkenalkan dan mengajarkan isi pokok Gaudium et Spes. Dalam bagian ini juga bisa dilihat siapa yang berani untuk memperkenalkan dan mengajarkan isi pokok Gaudium et Spes, berapa kali usaha itu dilaksanakan, bentuk-bentuk konkritnya seperti apa, apakah pelaksanaan usaha-usaha itu disertai dengan evaluasi. Kedua adalah menemukan data tentang pemahaman Gereja terhadap isi pokok Gaudius et Spes. Data mengenai pemahaman umat terhadap isi pokok ajaran Gaudium et Spes bisa dijadikan alat evaluasi apakan Gereja sudah memahami isi pokok Gaudium et Spes. Pemahaman ini bisa dijadikan titik tolak untuk meningkatkan kualitas pemahaman dan sekaligus mengimplementasikan pemahaman tersebut. Ketiga adalah melihat dan menginventarisasi gerakan hidup Gereja yang bisa dikategorikan sebagai bentuk implementasi ajaran Gaudium et Spes.

\subsection{Tujuan Penulisan}

Tujuan utama dari penelitian ini adalah untuk mengukur dan melihat langkah konkrit pembelajaran dan penerimaan terhadap Gaudium et Spes. Dengan kata lain, penelitian ini merupakan bentuk evaluasi terhadap upaya Gereja untuk menerima, memahami, dan mengimplementasikan Gaudium et Spes.

Tujuan lain dari penelitian ini adalah untuk menyediakan data evaluatif mengenai resepsi

Gereja terhadap Gaudium et Spes. Harapan selanjutnya, data ini berguna bagi bagi perencanaan dan upaya konrket untuk meningkatkan kualitas pemahaman dan penghayatan Gereja terhadap ajaran Konsili Vatikan II.

\subsection{Metode Penulisan}

Supaya dapat menemukan indikator-indikator yang jelas mengenai resepsi umat katolik atau Gereja Indonesia terhadap Konstitusi Gaudium et Spes, penulis akan mengadakan studi dokumen Gaudium et Spes secara analitis-sistematis. Metode studi dokumen secara analitis-sistematis bertujuan untuk mendapatkan uraian sistematis tentang isi pokok Gaudium et Spes.

Langkah selanjutnya adalah pemaparan contoh-contoh resepsi atas Gaudium et Spes dalam konteks Gereja Katolik Indonesia. Untuk itu, pada bagian kedua ini penulis akan menggunakan metode studi analisis kasus dan studi fenomenologis untuk menunjukkan indikator-indikator yang jelas terjadinya resepsi terhadap Gaudium et Spes. Penulis menampilkan kasus-kasus atau fenomena-fenomena historis yang mewarnai kehidupan Gereja Indonesia baik yang tampak dalam bentuk kebijakan institusi Gereja maupun gerakan kehidupan umat katolik (kelompok atau perorangan) yang bisa dikategorikan sebagai indikator terjadinya resepsi terhadap Gaudium et Spes.

\subsection{Landasan Teori}

Untuk memahami pengertian tema dan cakupan pembahasannya, berikut akan disampaikan uraian mengenai pengertian 
istilah konsili dan resepsi yang disertai dengan penjelasan proses resepsi konsili. Uraian ini menjadi dasar teori penelitian ini.

\subsubsection{Konsili}

Yang dimaksudkan dengan konsili adalah pertemuan pada tingkat regional atau universal (ekumene, semesta, dunia) yang diikuti oleh para wakil yang sah dari Gereja-Gereja (baca: keuskupan-keuskupan) untuk membicarakan dan memutuskan dengan kesatuan suara halhal yang menyangkut iman dan praktik serta pengorganisasian hidup Gereja. Sejak abad pertengahan, konsili hanya dipakai untuk menunjuk konsili universal atau dengan kata lain konsili ekumenis; sedangkan untuk tingkat regional tidak lagi digunakan kata konsili, melainkan sinode.

Penyelenggaraan Konsili biasanya berkaitan dengan tiga maksud: ${ }^{3}$ a) melawan ajaran sesat, b) mengusahakan kesatuan Gereja, dan c) membahasakan kembali ajaran-ajaran Gereja agar dapat dimengerti oleh manusia pada zamannya. Penelitian tentang resepsi atau penerimaan terhadap Gaudium et Spes berhubungan erat dengan maksud ketiga dari penyelenggaraan konsili, yakni menemukan beberapa indikasi penerimaan Gereja atau Umat Indonesia terhadap ajaran Konsili Vatikan II yang termuat dalam Konstitusi Gaudium et Spes.

\subsubsection{Resepsi Konsili}

Resepsi (penerimaan) konsili adalah sebuah proses rohani yang melaluinya keputusankeputusan yang dihasilkan oleh sebuah konsili diterima dan diasimilasikan (diserupakan, disatukan) ke dalam hidup sebuah Gereja lokal dan menjadi sebuah perwujudan hidup iman rasuli (iman apostolik). ${ }^{4}$ Disebut proses rohani karena, pertama, Roh Kuduslah yang menggerakkan sebuah Gereja lokal (keuskupan) untuk menerima dan mengasimilasikan keputusan-keputusan konsili ke dalam gerak hidup Gereja lokal tersebut. Kedua, proses asimilasi tersebut berujung pada pembaruan hidup Gereja lokal sebagai buah pertobatan. Ketiga, yang diasimilasi, yakni keputusankeputusan konsili tidak lain adalah harta rohani, yaitu iman yang diajarkan para rasul yang dirumuskan sesuai dengan pengertian zaman sekarang.
Proses penerimaan dan asimilasi hasil konsili berbeda dari satu Gereja lokal ke Gereja lokal lainnya. Ada beberapa faktor yang ikut menentukan lama waktu proses resepsi konsili, yakni: keadaan Gereja secara menyeluruh, sejarah Gereja lokal, dan terutama situasi budaya, sosial, ekonomi dan politik dari Gereja lokal. Apa yang disebut terakhir bisa disebut sebagai konteks Gereja lokal yang menerima konsili secara aktif. Konteks yang berbedabeda dari setiap Gereja lokal membuat proses resepsi konsili menghasilkan pembaharuan yang berbeda-beda pula.

\subsubsection{Tahap-Tahap Resepsi}

Proses resepsi dapat dibagi menjadi dua tahap besar: resepsi kerygmatik (pewartaan) dan resepsi praktis. Yang dimaksud dengan resepsi kerygmatik adalah segala usaha yang dilakukan oleh para gembala untuk memperkenalkan dan mempromosikan keputusan-keputusan konsili. Resepsi kerygmatik dapat berupa resepsi formal (resmi)-otoritatif seperti penerjemahan yang dilakukan secara resmi oleh Gereja lokal atau konferensi Gereja-Gereja lokal, ensiklik-ensiklik Paus yang muncul setelah konsili, surat gembala para uskup dan sebagainya. Selain itu terdapat pula resepsi yang tidak formal (tidak resmi), yang bukan berasal dari otoritas (pimpinan Gereja) yang dapat mengambil bentuk pendapatpendapat para teolog entah tertulis atau tidak, tulisan-tulisan rohani dan sebagainya. Para teolog akan melihat secara kritis keputusan-keputusan konsili dengan mengajukan pertanyaan apakah hasil-hasil konsili tersebut sesuai dengan ajaran iman para rasul.

Resepsi kerygmatik yang berujung pada pengetahuan akan hasil-hasil konsili tentu saja tidaklah cukup. Resepsi harus menjangkau tindakan dan kehidupan nyata dan konkret umat dengan mengubah dan membaruinya. Pembaruan atau perubahan perlu mengambil bentuk yang nyata, dapat dilihat dan dialami oleh umat. Inilah yang disebut dengan resepsi praktis. Pada tingkat resepsi praktis hasil-hasil konsili diwujudkan, dijadikan nyata (diaktualkan) dalam liturgi, hukum Gereja, katekese dan badan-badan (institusi-institusi). Misal, liturgi kita sekarang merupakan perwujudan konkrit Konstitusi Sacrosanctum Concilium. Demikian pula Hukum Gereja yang dipromulgasikan pada tahun 1983 dan Katekismus Gereja Katolik yang terbit pada 
tahun 1993. Muncul pula badan-badan baru seperti Konferensi Wali Gereja di setiap negara atau gabungan beberapa negara.

Resepsi praktis tidak berhenti pada liturgi, hukum Gereja, katekese dan pembentukan institusi-institusi, tetapi menjangkau batin, kesadaran, hidup rohani umat. Pembaruan institusi diikuti atau, lebih baik, seharusnya menolong pembaharuan rohani. Kesadaran (conscience), mentalitas, sikap, spiritualitas, praktek hidup Gereja diubah. Ia mengalami metanoia (pertobatan) yang merupakan karya Roh Kudus. Roh Kudus yang sama, yang dulu didengarkan oleh para uskup dalam konsili sekarang didengarkan oleh umat beriman. Oleh karena itu resepsi konsili biasanya memerlukan pengalaman berdoa, yang tidak lain adalah pengalaman mendengarkan Roh Kudus. Resepsi konsili dengan demikian adalah sebuah pengalaman akan Roh Kudus.

Yang digerakkan oleh Roh Kudus untuk secara aktif berperan dalam resepsi sebuah konsili adalah semua anggota Umat Allah, yakni: para gembala, teolog, awam dan biarawanbiarawati. Dari Roh Kudus kaum beriman ini menerima karisma yang berbeda-beda yang dengannya keputusan konsili diterima sehingga hasil penerimaannya pun dapat berbeda-beda pula. Pada saat yang bersamaan Roh Kudus adalah yang menyatukan karisma-karisma tersebut sehingga Gereja dapat terhindar dari perpecahan yang diakibatkan oleh penerimaan yang berbeda-beda terhadap hasil konsili. Organ kelihatan dari Roh Kudus yang menyatukan ini tidak lain adalah uskup sebuah Gereja lokal.

Peran uskup dalam sebuah resepsi konsili mencakup, pertama, mewartakan keputusankeputusan konsili kepada segenap umat beriman dalam keuskupannya sehingga mereka mengetahui keputusan-keputusan konsili tersebut (resepsi kerygmatik). Kedua, mengusahakan agar semua umat beriman berpartisipasi dalam resepsi konsili dengan mengadakan, misalnya, sinode keuskupan. Ketiga, mendukung penerimaan yang bermacam-macam atas hasil konsili dan sekaligus menjaga kesatuannya. Keempat, menjaga agar hasil penerimaan konsili yang khas keuskupannya masih berada dalam kesatuan seluruh Gereja.

Para teolog digerakkan oleh Roh Kudus untuk mendalami hasil-hasil konsili dan kemudian menyusun secara sistematis pemikiran tertentu tentang iman yang tersebar dalam keputusan- keputusan konsili. Misalnya saja konsep-konsep tentang Gereja yang tersebar dalam berbagai dokumen konsili ia himpun secara sistematis dalam sebuah buku. Ia juga diminta untuk melakukan tinjauan kritis atas hasil-hasil konsili berdasarkan iman rasuli Gereja.

Sedangkan pengenalan para awam tentang konsili biasanya bercorak intuitif, tidak tersusun secara sistematis seperti pada para teolog, tidak sampai pada penegasan yang tajam dalam sebuah konsep atau definisi. Para awam biasanya tidak secara langsung mengenal hasil-hasil konsili. Mereka mengenalnya lewat liturgi, katekese, kegiatan-kegiatan pastoral di paroki, khotbah para gembala, surat-surat pastoral uskup dan sebagainya. Pengetahuan akan hasil konsili ini pelan-pelan mengarah pada penerimaan hasilhasil konsili dalam wujud pertobatan hati, perilaku dan tindakan yang diperbarui.

Dengan demikian hasil konsili diterima, diresepsi oleh Magisterium (kuasa mengajar Gereja yang resmi, yakni para Uskup), magisterium (para pengajar teologi) dan umat yang membentuk sensus fidei (intuisi iman).

\section{KONSTITUSI PASTORAL GAUDIUM ET SPES}

Setelah dipahami apa yang dimaksud dengan resepsi sebuah konsili sekarang akan dibahas secara ringkas apa yang diresepsi, apa yang diterima, yakni Konstitusi Pastoral Gaudium et Spes. $^{5}$

\subsection{Latar Belakang dan Proses}

Di sini tidak mungkin untuk menyampaikan secara rinci latar belakang dan proses kelahiran GS. Yang akan dipaparkan hanyalah uraian singkat saja.

Selama kira-kira 150 tahun sebelum Konsili Vatikan II sikap Gereja pada umumnya terhadap dunia adalah sikap menutup diri terhadap dunia, amat reaktif dan bahkan mengecam dunia. Hal ini terjadi karena Gereja merasa keberadaannya diancam oleh dunia. Ilmu pengetahuan yang berkembang pesat dianggap mampu menerangkan segala sesuatu sehingga tidak diperlukan lagi penjelasan dari Gereja. Penerapan praktis ilmu pengetahuan dalam apa yang dikenal dengan nama teknologi memicu revolusi industri yang memberi janji konkrit akan hidup sejahtera. Dunia tidak lagi mengakui 
kekuasaan Gereja dan Tuhan. Sebagai gantinya revolusi Perancis menandaskan bahwa kekuasaan berasal dari rakyat.

Walaupun demikian ada sekelompok kecil pemikir (teolog) dalam Gereja yang mengajukan pandangan yang berbeda. Kemajuan ilmu pengetahuan, teknologi dan politik tidak dilihat sebagai ancaman. Oleh karena itu Gereja bisa bersikap positif terhadap dunia. Pendapat dan sikap sekelompok kecil teolog dalam Gereja inilah yang kemudian menjadi pendirian Konsili seperti tampak dalam dokumen-dokumen yang dihasilkannya, di antara lain GS. ${ }^{6}$

GS yang berbicara tentang sikap Gereja terhadap dunia tidak muncul dalam tema-tema yang dipersiapkan oleh panitia persiapan Konsili. Ide GS muncul di akhir persidangan Sesi I Konsili ketika para Bapa Konsili membahas tema de ecclesia (Tentang Gereja) yang nantinya menjadi Konstitusi Dogmatis Lumen Gentium. ${ }^{7}$ Tidak mengherankan kalau kemudian GS merupakan dokumen yang paling akhir dipromulgasikan.

Ketika pada tanggal 4 Desember 1962 Kardinal Suenens memberi tanggapan terhadap skema de ecclesia, ia mengatakan bahwa pembicaraan pada Sesi II dapat berjalan secara sistematis, kalau Konsili difokuskan pada tema tentang Gereja. Pembicaraan tentang Gereja sendiri harus terdiri dari dua bagian, yakni: Gereja ke dalam (ad intra) dan Gereja ke luar (ad extra). Pada bagian tentang Gereja ke dalam dibicarakan tentang hakikat Gereja, sedangkan pada bagian tentang Gereja ke luar dibahas tentang dialog Gereja dengan dunia. ${ }^{8}$ Dalam perkembangannya, pembahasan tentang hakikat Gereja menghasilkan dokumen Lumen Gentium, sedangkan dialog Gereja dan dunia menjadi tema GS. Naskah tentatif pembahasan tentang dialog Gereja dan dunia dikenal dengan sebutan Skema 17 yang kemudian menjadi Skema $13 .{ }^{9}$

Apa yang diusulkan oleh Kardinal Suenens berpangkal pada pidato radio Paus Yohanes XXIII sebulan sebelum Konsili dibuka, tepatnya pada tanggal 11 September 1962. Dalam pidato tersebut Yohanes XXIII berbicara di antaranya tentang kehidupan Gereja ke dalam (ad intra) dan Gereja ke luar (ad extra). Hal ini selaras dengan konstitusi apostolik Humanae Salutis yang diterbitkan pada hari Natal tahun 1961 untuk memanggil Konsili. Dalam konstitusi apostolik ini Yohanes XXIII menyatakan bahwa ia menghendaki agar Injil dipertemukan dengan kehidupan modern yang ditandai oleh kemajuan teknik dan ilmu pengetahuan dan bersifat sekular. ${ }^{10}$

Dalam pidato pembukaan Konsili pada 11 Oktober 1962 Paus menandaskan bahwa Konsili diadakan tidak untuk mengutuk dunia, tetapi untuk menjelaskan ajaran iman Gereja dengan cara yang dapat dimengerti oleh orang-orang zaman sekarang. ${ }^{11}$

\subsection{Kualifikasi Dokumen}

Konsii Vatikan II menghasilkan 16 dokumen, yang terdiri dari 4 konstitusi, 9 dekrit dan 3 pernyataan (deklarasi). Keempat konstitusi tersebut adalah Konstitusi Sacrosanctum Concilium tentang Liturgi Suci, Konstitusi Dogmatis Lumen Gentium tentang Gereja, Konstitusi Dogmatis Dei Verbum tentang Wahyu Ilahi dan Konstitusi Pastoral Gaudium et Spes tentang Gereja dalam Dunia Modern. Kalau dekrit berarti petunjuk atau perintah konkret untuk keadaan tertentu, apa yang dimaksud dengan konstitusi dan kemudian apa itu konstitusi pastoral? Apa beda konstitusi pastoral dari konstitusi dogmatik?

Kita tentu mengetahui bahwa UUD 1945 merupakan konstitusi negara kita. Dengan itu dimaksudkan bahwa UUD 1945 menjadi dasar bagi segalah apa yang dilaksanakan oleh negara dan rakyatnya dan dengan demikian memberi bentuk pada negara tersebut. Demikian pula kalau GS disebut sebagai konstitusi, maka GS ini menjadi dasar bagi aktifitas Gereja dan memberinya bentuk. Padahal satu-satunya dasar yang membentuk kehidupan Gereja adalah iman. Oleh karena itu dapat disimpulkan bahwa GS mengandung kebenaran-kebenaran iman. Kalau pada Lumen Gentium dan Dei Verbum kebenaran-kebenaran iman tersebut pertamatama hendak dirumuskan dan disadari secara eksplisit sehingga keduanya mendapat kualifikasi konstitusi dogmatis, maka GS tidak berhenti pada perumusan dan penyadaran, tetapi mengarah pada perwujudan dan penghayatan iman dalam situasi hidup yang konkrit dan oleh karena itu sebagai konstitusi GS bercorak pastoral. Pastoral di sini berarti segala kegiatan Gereja yang membuat iman berarti dan relevan dalam hidup manusia. Penghayatan iman dalam peristiwa sejarah yang konkrit ini tidak hanya bercorak individual melainkan penghayatan seluruh anggota Gereja yang dibimbing oleh Roh Kudus, yang tampak secara sakramental dalam diri hirarki Gereja. ${ }^{12}$ 
Dalam rangka ini apa yang disebut oleh Yohanes XXIII berdasarkan Mat. 16:3 sebagai tanda-tanda zaman ${ }^{13}$ menjadi penting. Apa yang dimaksud dengan tanda-tanda zaman? Peristiwa yang penting atau kerap terjadi pada periode waktu tertentu dapat disebut sebagai ciri dari periode waktu tersebut. Sampai di sini peristiwa historis ini belum dapat disebut sebagai tanda zaman secara teologis. Ia baru bisa disebut tanda zaman yang sejati ketika dipahami bahwa dalam peristiwa historis ini bisa jadi Allah hadir dengan rahmatNya dan ditanggapi manusia dengan iman, tetapi bisa juga Ia tidak hadir. Dengan demikian kegiatan pastoral pertamatama adalah usaha menemukan iman akan Allah yang sudah ada dalam diri manusia yang terlibat dalam peristiwa historis tertentu tersebut dan kemudian mengembangkannya. Jadi, pastoral bukanlah membawa iman kepada manusia, tetapi membantu manusia menyadari iman akan Allah yang sudah dimilikinya. ${ }^{14}$

Dengan demikian menjadi jelas bahwa menurut GS yang menjadi rumah Allah (gereja, kapel) tidak lain adalah dunia yang dibentuk oleh peristiwa-peristiwa sejarah yang konkrit.

\subsection{Hubungan Keempat Konstitusi}

Bersama ketiga konstitusi yang lain GS memberi dasar dan bentuk bagi kehidupan Gereja. Bagaimana hubungan keempat konstitusi ini? Lumen Gentium membahas Gereja sejauh apa yang khas gerejani. Sacrosanctum Concilium berkonsentrasi pada aspek tertentu dari apa yang khas gerejani dari Gereja, yakni liturgi. Dei Verbum menempatkan keduanya dalam kanvas besar sejarah pewahyuan diri Allah yang menyelamatkan manusia. Dengan cara demikian Gereja tidak mengarah kepada dirinya sendiri, tetapi terarah kepada pelayanan umat manusia. Nah, GS-lah yang secara konkrit menuntun Gereja dalam dialognya dengan dunia. ${ }^{15}$

\subsection{Isi GS}

\subsubsection{Garis Besar}

GS terdiri dari 93 nomor dan dengan demikian merupakan dokumen Konsili yang paling panjang. Ke-93 nomor tersebut dibagi dalam empat bagian.

Nomor 1-10 membentuk Pendahuluan dan penjelasannya. Nomor 3 memberi per- nyataan penting yang dapat menjadi kunci untuk memahami GS. Menurut artikel tersebut “... manusia, ditinjau dalam kesatuan dan keutuhannya, beserta jiwa maupun raganya, dengan hati serta nuraninya, dengan budi dan kehendaknya, akan merupakan poros seluruh uraian kami".

Nomor 11-45 membangun Bagian Kedua. Pada bagian ini disampaikan ajaran-ajaran iman tentang manusia (12-39) dan tentang panggilan Gereja untuk berperan dalam dunia modern (4045) dengan rincian sebagai berikut:

1. Nomor 12-22: Martabat Manusia

2. Nomor 23-32: Masyarakat Manusia

3. Nomor 33-39 : Kegiatan Manusia.

Bagian Ketiga yang terdiri dari nomor $46-$ 90 merupakan sasaran utama Konsili. Dibahas beberapa masalah penting yang dihadapi dunia:

1. Nomor 47-52: Martabat Perkawinan dan Keluarga

2. Nomor 53-62: Pengembangan Kebudayaan

3. Nomor 63-72: Kehidupan Sosial Ekonomi

4. Nomor 73-76: Hidup Bernegara

5. Nomor 77-90: Usaha Perdamaian dan Pembentukan Persekutuan Bangsabangsa.

Nomor 91—93 menjadi bagian Penutup.

\subsubsection{Manusia Menurut Perwahyuan Kristiani: Pribadi, Makhluk Sosial dan Pekerja}

Telah dikatakan di depan bahwa sebuah konstitusi berbicara tentang apa yang membentuk kehidupan Gereja, yakni kebenaran-kebenaran iman. Dalam GS kebenaran iman yang dimaksud adalah kebenaran iman tentang manusia.

Mengikuti Kitab Kejadian manusia dilihat oleh GS sebagai citra (gambar) Allah. Keserupaan dengan Allah terletak pada, pertama, kemampuannya untuk berelasi dengan Allah dan ini sekaligus menjadi panggilan utamanya. $K e d u a$, ia diberi kuasa untuk menata dunia dan segala isinya sesuai dengan apa yang dikehendaki Allah. Ketiga, ia hidup tidak sendirian tetapi bersama dengan orang lain (makhluk sosial). Keserupaan ini rusak, walaupun tidak total, oleh dosa yang dilakukan manusia. Oleh karena itu walaupun pada dasarnya badan dan jiwa manusia itu baik karena diciptakan oleh Allah, 
dosa membuatnya memberontak terhadap badannya; walaupun akal budi itu baik sehingga ia terdorong untuk mencapai kebenaran terdalam, dosa melemahkan usahanya; walaupun dengan hati nuraninya manusia mampu mendengarkan perintah Allah, dosa bisa membuat hati nuraninya tersesat; walaupun manusia memiliki kebebasan, dosa tidak jarang mengubah kebebasan menjadi kesewenang-wenangan; walaupun ia dipanggil untuk hidup abadi, manusia tetap gentar menghadapi maut; walaupun ia dicipta untuk berelasi dengan Allah, dosa menggiring manusia kepada ketidakpercayaan pada Allah (ateisme).

Pada diri Yesus Kristus citra Allah itu tidak terluka oleh dosa dan lebih daripada itu mencapai kesempurnaannya. Kodrat manusiawi yang diperoleh lewat penciptaan tidak dienyahkan melainkan disempurnakan oleh Kristus, Adam baru. Oleh karena kita menerima RohNya, maka kodrat manusiawi yang dilukai oleh dosa dipulihkan dan disempurnakan olehNya.

Setelah menguraikan pandangan tentang manusia sebagai pribadi dari sudut iman, GS menampilkan teologi manusia sebagai makhluk sosial. Allah menciptakan manusia dalam kesatuan dengan manusia yang lain dan Ia menyelamatkan mereka tidak hanya orang per orang melainkan juga sebagai umat manusia. Yesus Kristus menjadi manusia bersama manusia yang lain dan lewat wafat dan kebangkitanNya Allah menghimpun sebuah Umat yang merupakan rahmat bagi dunia. Persatuan putera-puteri Allah dalam Umat ini (Gereja) menyerupai persatuan Pribadi-Pribadi Ilahi (Allah Tritunggal).

Sifat sosial manusia mendorong manusia untuk hidup dalam perhimpunan-perhimpunan sosial. Dari satu pihak manusia memang memerlukan hidup kemasyarakatan yang terwujud secara konkrit dalam lembaga-lembaga sosial ini; dari lain pihak hidup kemasyarakatan ini ada untuk perkembangan pribadi manusia dan bukan sebaliknya. Agar tujuan ini tercapai masyarakat perlu mengusahakan kesejahteraan umum, setiap pribadi manusia dihormati dan diperlakukan secara sama, martabat pribadi manusia dijaga dengan menciptakan kondisi hidup yang manusiawi dan adil, dan dalam masyarakat setiap manusia melakukan kewajiban-kewajiban yang dituntut oleh hidup bersama.

Manusia yang bercorak personal dan sosial tersebut adalah manusia yang berkegiatan, bekerja. Dari sudut pandang wahyu dan iman kristiani bekerja untuk memperbaiki kesejahteraan hidup adalah perwujudan dari kehendak Allah agar manusia menguasai dunia dalam keadilan dan kesucian. Norma yang harus dipegang dalam bekerja adalah bahwa pekerjaan harus selaras dengan kesejahteraan sejati manusia. Dalam bekerja manusia tidak hanya mengubah hal-hal di luar dirinya, tetapi juga mengembangkan bakat-bakatnya dan keluar dari dirinya sendiri. Kegiatan-kegiatan yang dilakukan oleh masyarakat manusia ini dan ilmu pengetahuan yang mendukungnya memiliki otonominya sendiri dan diakui oleh Gereja. Gereja menghormati hukum-hukum dan tata susunan pekerjaan yang membentuk dunia manusia tersebut. Walaupun demikian otonomi yang dimaksud bukanlah otonomi yang absolut, melainkan terarah pada Allah juga (otonomi relatif).

Kegiatan-kegiatan manusia yang-memakai istilah Kitab Kejadian - baik adanya ini dirusak oleh dosa. Manusia dan berbagai kelompok mementingkan dirinya sendiri dan dengan demikian menyengsarakan sesama. Bahkan manusia ditindas oleh pekerjaan yang berlebihan, tanpa waktu istirahat dan upah yang memadai. Akan tetapi Roh Kudus yang diberikan oleh Allah lewat peristiwa wafat dan kebangkitan PuteraNya membuat manusia menjadi ciptaan baru yang mampu melaksanakan pekerjaanpekerjaannya dengan semangat cintakasih Yesus Kristus sendiri, sehingga dapat menciptakan di masa depan kesejahteraan manusiawi yang dapat menjadi landasan bagi kerajaan surgawi, yakni langit dan bumi yang baru.

\subsubsection{Hubungan Gereja dan Dunia Secara Umum}

Pandangan dari sudut iman tentang martabat pribadi manusia, masyarakat manusia dan manusia sebagai makhluk yang bekerja menjadi dasar dan kerangka hubungan timbal balik antara Gereja dan dunia.

Gereja memiliki tujuan rohani, yakni mengantar orang untuk berjumpa dengan Allah dan dilengkapi dengan harta-harta rohani seperti misalnya rahmat yang dikandung oleh berbagai sakramen. Selain bercorak rohani sekaligus Gereja itu sesuatu yang jasmani seperti tampak dalam lembaga-lembaga dan perhimpunan orang-orangnya. Sebagai yang rohani dan jasmani ini Gereja hadir di tengah-tengah dunia 
dan mengalami suka dan duka dunia karena memang warganya adalah juga warga dunia. Dengan rumusan yang lebih tepat, masyarakat manusia memiliki dimensi gerejani dan duniawi. Keduanya memiliki bukan satu arah tetapi hubungan timbal balik. Dari satu pihak Gereja hadir ibarat ragi bagi dunia. Ia menyalurkan hidup ilahi kepada dunia dengan-mengikuti kerangka di atas-:

1. Menyembuhkan dan mengangkat martabat pribadi manusia.

2. Meneguhkan kehidupan bersama masyarakat manusia dengan mengusahakan kesejahteraan umum.

3. Memberi makna yang mendalam pada pekerjaan (kegiatan) manusia.

Yang dilakukan Gereja bagi dunia sejauh menyangkut martabat pribadi manusia adalah menimbulkan kesadaran bahwa makna yang terdalam dari pribadi manusia adalah hubunganNya dengan Allah. Keinginan hati manusia yang terdalam hanya dapat dipuaskan dalam Allah. Oleh karena itu Gereja menghormati suara hati tempat manusia mendengarkan gema suara Allah dan mengarahkan kegiatan manusia pada pengabdian kepada Allah. Selain itu Gereja juga mewartakan hak-hak asasi manusia.

Sedangkan menyangkut masyarakat manusia Gereja dituntut justru oleh tujuan rohaninya untuk meneguhkan kesatuan dengan di antaranya turut serta mengatasi konflik dan meningkatkan kesejahteraan hidup bersama manusia dengan membangkitkan kegiatan-kegiatan melayani semua orang, khususnya mereka yang miskin dan sengsara. Oleh karena itu Gereja mendukung berbagai lembaga yang memiliki keprihatinan yang sama. Gereja mengupayakan semua ini dengan kekuatan iman dan cintakasih.

Akhirnya, Gereja mendesak para anggotanya, khususnya kaum awam untuk menunaikan pekerjaan-kewajiban duniawi mereka tidak hanya dengan sekedarnya saja tetapi dengan sungguh bermutu dan berprestasi sehingga mereka dapat menjadi garam dunia dan saksi Kristus.

Semuanya ini dilakukan oleh Gereja agar umat manusia dapat mengalami cintakasih Allah. Gereja memang adalah sakramen keselamatan bagi seluruh umat manusia.

Dari lain pihak dunia juga memberi sumbangan bagi Gereja. Pengembangan masyarakat dalam bidang hidup berkeluarga, ekonomi, politik nasional dan internasional, dan budaya memberi bantuan yang amat berarti pada jemaat Gereja. Kemajuan dalam ilmu pengetahuan dan kebudayaan membantu Gereja untuk memahami Injil dengan lebih mendalam dan untuk mewartakannya sesuai dengan perkembangan zaman.

Saling membantu antara Gereja dan dunia dimaksudkan agar Kerajaan Allah datang dalam wujud kesejahteraan umat manusia.

\subsubsection{Penghayatan Kebenaran Iman tentang Manusia Dalam Hidup dan Masalah- Masalah Konkrit}

Kebenaran-kebenaran iman tentang martabat manusia, masyarakat manusia dan kegiatan manusia dipakai untuk menerangi masalahmasalah yang dihadapi oleh umat manusia dan menjadi pedoman bagi karya Gereja di tengahtengah dunia. Tentu saja di luar jangkauan Konsili untuk menelaah semua permasalahan yang dihadapi dunia. Konsili memilih masalahmasalah yang menurutnya amat membebani umat manusia dan mendesak untuk diatasi, yaitu masalah dalam bidang perkawinan dan keluarga, kebudayaan, ekonomi, negara dan perdamaian dunia. Dalam bidang-bidang kehidupan inilah manusia melaksanakan kegiatan-kegiatannya dengan menghormati dan mengembangkan martabat pribadi manusia dan kesejahteraan seluruh masyarakat.

\subsubsection{Perkawinan dan Keluarga}

Dari satu pihak Konsili melihat ada upayaupaya untuk mengembangkan cintakasih dalam hidup berkeluarga. Dari lain pihak Konsili tidak menutup mata akan ancaman-ancaman terhadap hidup perkawinan: perceraian, percintaan bebas, poligami, cara-cara tidak halal melawan timbulnya keturunan dan sebagainya.

Konsili memandang perkawinan sebagai persekutuan hidup suami-isteri yang diadakan oleh Allah sendiri, dibangun oleh persetujuan bebas pribadi-pribadi dan dilembagakan oleh penyerahan diri timbal balik (sanggama) dan menjadi sakramen yang menandakan cinta antara Kristus dan Gereja yang oleh karenanya menjadi tidak terceraikan. Tujuan perkawinan mencakup cintakasih suami-isteri yang membahagiakan dan membuat kepribadian mereka menjadi penuh dan penerusan keturunan. Dengan demikian kemantapan hidup masyarakat manusia terjamin. 
Konsili memusatkan perhatian terutama pada masalah penghambatan penerusan keturunan. Menurut Konsili penerusan keturunan adalah partisipasi manusia pada karya penciptaan dan penyelamatan Allah. Kehidupan sejak pembuahan harus dilindungi dan pengguguran dinilai sebagai pembunuhan. Menyangkut anak yang sudah lahir dan yang mereka perkirakan masih akan ada suami dan isteri "tidak dapat mengambil langkah-langkah semaunya sendiri saja; tetapi selalu harus dituntun oleh suara hati, yang harus disesuaikan dengan hukum ilahi sendiri; mereka harus menganut bimbingan Wewenang Mengajar Gereja, yang dalam terang Injil memberi tafsiran otentik kepada Hukum itu" (No. 50).

\subsubsection{Kebudayaan}

Kebudayaan dilihat oleh Konsili sebagai "segala sarana dan upaya manusia untuk menyempurnakan dan mengembangkan pelbagai bakat-pembawaan jiwa raganya (manusia)" (No. 53). Upaya-upaya itu mencakup pengembangan ilmu pengetahuan untuk menguasai alam semesta, pengembangan tata susila dan berbagai lembaga agar kehidupan bersama umat manusia menjadi lebih manusiawi dan pengungkapan dan pelestarian pengalaman-pengalaman rohani lewat karya-karya (seni).

Masalah yang ditemukan oleh Konsili adalah di antaranya, pertama, ada bahaya bahwa perjumpaan antar budaya dan perluasan budaya baru yang ditimbulkan oleh modernitas meminggirkan budaya-budaya lokal. Kedua, bagaimana caranya agar sebanyak mungkin orang dapat mengalami nilai-nilai budaya dunia? Ketiga, apa yang harus dibuat agar budaya tidak merosot menjadi sesuatu yang manusiawi melulu, melainkan mengantar manusia pada Penciptanya?

Pada dasarnya Gereja, lewat Konsili mendorong para anggotanya untuk mengembangkan kebudayaan. Persoalan pertama tidak secara eksplisit ditangani oleh Konsili. GS hanya mengatakan bahwa semua manusia berhak atas kebudayaan manusiawi. Oleh karena itu kebudayaan harus tetap ada dan berkembang, termasuk budaya-budaya lokal. Sedangkan untuk mengatasi persoalan kedua perlulah Gereja turut serta menyediakan harta kebudayaan bagi semua orang, terutama kebudayaan mendasar seperti kemampuan untuk membaca dan menulis. Hal ini dilakukan oleh Gereja terutama lewat pendidikan.
Akhirnya, dari satu pihak budaya menyiapkan manusia untuk menerima Injil, menjadi sarana pewartaan, membantu manusia untuk mendalami pesan-pesan Injil dan dapat dimanfaatkan untuk mengungkapkannya dalam liturgi. Dari lain pihak, Injil atau, dengan kata lain, iman, membarui kebudayaan dengan menjernihkannya dari segala kesesatan dan kemalangan dan mengangkatnya ke tingkat yang lebih tinggi.

\subsubsection{Kehidupan Sosial Ekonomi}

Kehidupan sosial ekonomi masyarakat dilaksanakan dengan menghormati martabat manusia dan untuk pengembangan pribadi manusia dan kesejahteraan umum. Masalah yang disorot oleh GS adalah ketimpangan sosial-ekonomi yang besar di antara sebagian kecil yang kaya dan golongan massa yang miskin. Perbedaan ini perlu dihilangkan dengan menjalankan tata sosial ekonomi yang adil yang disertai cintakasih. Keadilan juga mencakup generasi yang akan muncul di masa depan. Selain itu beberapa prinsip perlu diperhatikan.

Pertama, kerja lebih penting daripada saranasarana ekonomi yang lain. Melalui kerja manusia mengungkapkan dan mewujudkan dirinya ; menaruh cap atas benda-benda dan membuat mereka mengikuti kehendaknya. Dengan kerja manusia digabungkan dengan karya penebusan Yesus Kristus yang memberi martabat mulia pada kerja dengan bekerja sebagai tukang kayu. Lewat kerja manusia dapat bagi dirinya sendiri dan keluarganya memelihara dan mengembangkan kehidupan jasmani, budaya, social, dan rohani dan oleh karena itu ia harus mendapat upah yang memungkinkannya melakukan tanggungjawabnya tersebut. Mengingat penting dan mendasarnya kerja, maka manusia memilik hak atas kerja.

Kedua, dalam kegiatan-kegiatan ekonomi seperti misalnya dalam perusahaan tidak hanya pimpinan yang berperan aktif dalam penentuan kebijaksanaan perusahaan, tetapi juga buruh. Untuk itu buruh memiliki hak untuk berserikat. Ketika terjadi konflik, pertama-tama diambil jalan musyawarah, tetapi dalam keadaan-keadaan tertentu buruh bisa menjalankan aksi mogok.

Ketiga, benda-benda di bumi diperuntukkan untuk semua orang. Memang orang perlu memiliki harta secukupnya, tetapi harta yang ia miliki juga adalah milik umum, dalam arti dapat berguna tidak untuk dirinya sendiri. Dalam 
"menghadapi kebutuhan darurat, orang berhak untuk mengambil dari kekayaan orang-orang lain apa yang sungguh dibutuhkannya" (No. 69). Orang wajib menolong orang yang lapar tidak hanya dari kelebihannya:"Berilah makan kepada orang yang akan mati kelaparan; sebab bila engkau tidak memberi makan, engkau membunuhnya" (No. 69).

Keempat, orang memiliki hak atas milik pribadi. Milik pribadi berperan untuk pengungkapan pribadi, otonomi, keamanan, perluasan kebebasan dan pelaksanaan kewajiban. Walaupun demikian milik pribadi memiliki corak sosial seperti telah dijelaskan di atas sehingga tertutup peluang untuk bertindak serakah.

\subsubsection{Hidup Bernegara}

Oleh karena orang-orang, keluarga, pelbagai kelompok tidak mampu mengusahakan kesejahteraan, maka mereka membentuk negara untuk menciptakan kesejahteraan umum. Inilah landasan keberadaan negara. Demi pencapaian tujuan ini diperlukan pemerintah dan orang-orang yang menjalankan pemerintahan. Setiap warga negara berhak untuk berperan serta menetapkan dasar negara, sistim pemerintahan dan memilih pejabat pemerintah. Negara juga melindungi hakhak pribadi warganya seperti hak berpendapat dan menyampaikannya, berserikat, beragama dan mengamalkannya dan sebagainya. Dari lain pihak, warga negara memiliki kewajiban untuk memajukan kesejahteraan umum. Partaipartai politik wajib untuk mendukung apa yang menurut mereka memajukan kesejahteraan umum. Keuntungan partai tidak boleh didahulukan terhadap kesejahteraan umum. Menjadi politikus adalah panggilan yang luhur sejauh ia tidak mengutamakan kepentingan pribadi dan keuntungan material. Warga wajib taat berdasarkan hati nurani kepada pemerintah yang dipilih dan yang menjalankan kekuasaannya sesuai dengan batas-batas tata moral dan untuk kesejahteraan umum. Bila tidak, warga negara dapat memperjuangkan hak-hak mereka dengan melawan penyalahgunaan kekuasaan dengan cara yang sesuai dengan Injil.

Walaupun Gereja dan negara otonom di bidangnya masing-masing dan berdasarkan alasan yang berbeda keduanya dapat bekerjasama dalam memajukan kesejahteraan umum.

\subsubsection{Perdamaian dan Persekutuan Bangsa- Bangsa}

Keprihatinan terakhir yang dibicarakan oleh GS adalah perang. Ketika Konsili berlangsung dunia dilanda perang dingin antara blok barat melawan blok timur (komunis). Kedua belah pihak memiliki persenjataan militer yang amat canggih berkat kemajuan ilmu dan teknologi. Oleh karena itu dari satu pihak perang dapat menimbulkan korban yang demikian banyak dan demikian mengerikan dan dari lain pihak menyeret pelaku pada perbuatan jahat yang amat keji. Keduanya berlawanan dengan perlindungan akan martabat pribadi manusia dan usaha kesejahteraan umum. Tidak mengherankan kalau GS menentang pelaksanaan perang. Satu-satunya perang yang boleh dilakukan adalah perang untuk mengadakan pembelaan diri.

Yang diserukan oleh Konsili adalah agar diadakan usaha-usaha perdamaian. Perdamaian yang dimaksudkan bukanlah suasana damai yang diusahakan dengan penguatan alat-alat perang yang menimbulkan ketakutan pada pihak lain yang kemudian tidak berani melawan. Menurut GS damai sejati adalah damai yang merupakan buah dari karya keadilan. Sering ketidakadilan memicu konflik dan perang. Ketimpangan ekonomi yang mengakibatkan kemiskinan mendorong orang untuk mengangkat senjata.

Damai yang sejati memerlukan cintakasih. Selain menggerakkan orang untuk bertindak adil, cinta mendorong orang untuk membentuk ikatanikatan persaudaraan. Ikatan-ikatan ini pada kenyataannya bahkan sampai pada pembentukkan badan-badan kerjasama internasional. Lewat lembaga-lembaga internasional bangsa-bangsa dapat bekerjasama untuk memberantas kemiskinan yang disebabkan oleh ketidakadilan.

\section{RESEPSI GEREJA INDONESIA TERHADAP GAUDIUM ET SPES}

Telah dijelaskan di depan bahwa tujuan akhir dari sebuah proses resepsi sebuah hasil konsili adalah bahwa ajaran iman yang berasal dari para rasul yang diteruskan oleh konsili terwujud secara konkret dalam kehidupan Gereja lokal. Ajaran rasuli yang disampaikan oleh konsili dalam GS adalah ajaran tentang manusia, masyarakat manusia dan kegiatan-kegiatannya. 


\subsection{Konteks}

Resepsi atau penerimaan konsili sendiri tergantung terutama pada situasi budaya, sosial, ekonomi dan politik Gereja lokal. Dalam kasus Indonesia beberapa situasi dapat disebut. Pertama, masyarakat Indonesia adalah masyarakat yang majemuk dalam hal budaya, agama dan etnis. Kedua, Indonesia memiliki kebudayaan yang kaya nilai dan ekspresi dan sekaligus menghadapi tantangan berupa penyeragaman dan tak jarang kepunahan sebagai resiko berhimpun dalam negara Indonesia dan sebagai akibat globalisasi. Ketiga, mayoritas penduduknya beragama Islam, sedangkan umat Katolik menjadi minoritas di dalamnya. Keempat, walaupun kesejahteraan penduduk Indonesia meningkat masih banyak penduduk yang miskin, yang mengakibatkan kebodohan dan mutu kesehatan yang buruk. Kelima, masih banyak terjadi berbagai bentuk ketidakadilan sosial. Keenam, korupsi yang merajalela. Ketujuh, penegakkan hukum yang lemah. Kedelapan, sekarang Indonesia hidup dalam alam kebebasan demokrasi setelah tigapuluhtahun lebih dikuasai oleh rezim otoriter Orde Baru.

\subsection{Tahap-Tahap}

Seperti juga telah diuraikan dalam bagian pertama dari makalah ini penerimaan hasil konsili mengalami proses dari tahap kerygmatik (pewartaan) ke tahap praktis. Batas di antara keduanya sering tidak demikian jelas.

\subsubsection{Tahap Pewartaan (Kerygmatik)}

Pertama-tama GS sebagai hasil Konsili Vatikan II perlu diberitakan oleh para gembala Gereja Indonesia (uskup dan para imam) kepada umatnya agar dapat dipahami oleh umat. Oleh karena teks asli GS dan dokumendokumen lain ditulis dalam bahasa Latin, maka perlu diterjemahkan terlebih dulu. Oleh karena itu padan tahun 1983 MAWI—sekarang KWI-melalui Departemen Dokumentasi dan Penerangan (Dokpen) mengeluarkan terjemahan dokumen-dokumen Vatikan II dengan judul Tonggak Sejarah Pedoman Arah. Penerjemahan dilakukan oleh J. Riberu. Boleh dinilai bahwa pengerjaan dan penerbitan terjemahan Indonesia ini terjadi lama setelah Vatikan II berakhir, yakni delapanbelas (18) tahun. Oleh karena hasil terjemahan dinilai tidak memuaskan,
Dokpen KWI menerbitkan terjemahan baru yang dilakukan oleh R. Hardawiryana pada tahun 1993. Itu berarti 28 tahun setelah Konsili Vatikan II.

Para teolog sebagai magisterium (wewenang mengajar) non-formal juga berusaha menjelaskan GS. Tom Jakobs menulis seri buku yang merupakan penjelasan dan komentar atas dokumen Vatikan II. Secara khusus ia menulis buku berjudul Latar Belakang Gaudium et Spes. Ia juga menulis buku Gereja menurut Vatikan II yang di antaranya membahas Gereja yang terlibat di tengah masyarakat. Upaya Tom Jakobs merupakan bentuk konkrit pengajaran GS kepada Gereja Indonesia.

Sementara itu di bangku sekolah-sekolah tinggi filsafat dan teologi diajarkan mata kuliah Ajaran Sosial Gereja yang tidak lain adalah sistematisasi dan pengembangan GS. Hal ini secara tidak langsung bisa dikategorikan sebagai upaya untuk mengajarkan isi pokok GS.

Pada umumnya isi ajaran GS sampai kepada umat Indonesia bukan dalam bentuk tulisan yang murni bicara tentang GS, tetapi tulisan atau seruan-seruan yang memanfaatkan GS untuk pembangunan Gereja Indonesia dan untuk menangani masalah-masalah yang sedang dihadapinya di tengah dan bersama masyarakat Indonesia.

Sudah pada tahun 1970 MAWI menerbitkan Pedoman Kerja Umat Katolik seluruh Indonesia, yang bertujuan untuk membantu umat Katolik berpartisipasi dengan tepat dalam pembangunan masyarakat Indonesia. Dapat diduga bahwa semangat dan tulisan GS menjadi acuan bagi Pedoman tersebut. Dua puluh lima (25) tahun kemudian, pada tahun 1995 KWI menggantinya dengan menerbitkan Pedoman Gereja Katolik Indonesia. Tujuannya untuk membarui keterlibatan umat Katolik upaya menyejahterakan seluruh rakyat Indonesia. Oleh karena itu Pedoman ini berbicara tentang keterlibatan dalam membangun hidup berkeluarga, ekonomi dan budaya. Tema-tema ini sama persis dengan apa yang ditemukan dalam GS. Hanya saja Pedoman menambah tema-tema yang sebenarnya telah ada secara implisit di dalam GS atau telah disinggung secara sambil lalu olehnya: hubungan perempuan dan laki-laki, kaum muda, pendidikan, layanan kesehatan dan komunikasi sosial. Sekaligus di sini terlihat kemunculan secara lebih kelihatan problem-problem baru. 
Setahun kemudian, pada tahun 1996 KWI melalui Komisi Kateketik menerbitkan buku Iman Katolik yang dimaksudkan juga sebagai katekismus yang didasarkan pada Vatikan II tetapi dengan memperhatikan situasi khusus Indonesia. ${ }^{16}$ Pada halaman 444 sampai dengan 460 dapat ditemukan penyampaian dalam konteks Indonesia tema-tema yang ada pada GS: Gereja dan Masyarakat, Gereja dan Kaum Miskin dan Gereja dan Negara Republik Indonesia.

Kemudian pada tahun 2000, 2005 dan 2010 Gereja Indonesia mengadakan Sidang Agung (SAGKI). Sidang Agung yang kedua membicarakan persoalan korupsi, kemiskinan, pengangguran, kriminalitas, perburuhan, pertanian, lingkungan hidup, pendidikan dan layanan kesehatan. Sekali lagi kita melihat di sini penerimaan (resepsi) GS. Perlu dicatat bahwa baik Sidang Agung maupun proses pembuatan Pedoman Gereja Indonesia (1995) mengikutsertakan perwakilan-perwakilan awam. Dengan demikian tuntutan yang diminta oleh resepsi agar semua anggota Umat Allah dilibatkan dipenuhi.

Selain itu masih perlu dicatat nota-nota pastoral atau apa saja namanya yang dikeluarkan oleh uskup-uskup Indonesia setiap kali mereka selesai mengadakan sidang tahunan. Kebanyakan temanya berbicara tentang masalah yang dihadapi masyarakat Indonesia dan bagaimana sikap Gereja Indonesia.

Dokumen-dokumen tersebut tidak dibaca oleh kebanyakan umat. Yang sampai pada umat secara langsung biasanya adalah, pertama, Surat Gembala baik yang dikeluarkan oleh KWI maupun oleh setiap uskup di keuskupannya masing-masing untuk menyambut Hari Raya Paskah dan Natal. Surat-surat Gembala tersebut selalu menyinggung permasalahan yang sedang dihadapi masyarakat Indonesia dan bagaimana umat harus bersikap dan bertindak. Hal ini sesuai dengan jiwa GS.

Kedua, tema-tema Aksi Puasa Pembangunan yang direnungkan secara bersama-sama di kringkring juga sering membahas persoalan-persoalan yang sedang dihadapi masyarakat Indonesia dan bagaimana umat harus bersikap. Tema-tema tersebut adalah misalnya saja martabat manusia, lingkungan hidup, kerja dan sebagainya. Renungan bersama ini dilakukan dalam sebuah ibadat. Dengan demikian resepsi yang sejati, yakni resepsi sebagai karya Roh diberi peluang untuk terjadi.

\subsubsection{Penerimaan Praktis}

Sebenarnya apa yang menjadi roh dan isi GS sampai pada umat lebih oleh keberadaan dan kegiatan badan-badan Gereja yang ada pada tingkat KWI, keuskupan maupun paroki dan lembaga-lembaga kerasulan lainnya. Beberapa dapat disebut: Komisi Keluarga, Komisi Pengembangan Sosial Ekonomi, Komisi Keadilan dan Perdamaian, Komisi Pendidikan, Komisi Kerasulan Awam, Perdaki dan perpanjangannya pada tingkat keuskupan dan paroki. Komisi-komisi ini boleh dikatakan sebagai hasil pembaruan yang dilakukan oleh GS pada kehidupan menggereja. Lembaga-lembaga kerasulan lainnya berasal dari inisiatif ordo/ konggregasi biarawan-biarawati dan kelompokkelompok awam.

Walaupun demikian keberadaan lembagalembaga tersebut bisa bersifat formalitas belaka. Oleh karena itu penerimaan (resepsi) konsili selanjutnya menuntut agar kegiatan-kegiatan yang dilakukan oleh komisi-komisi dan unsurunsur lain dalam Gereja membarui kehidupan Gereja. Dalam kasus GS perlu ditanyakan apakah Gereja Indonesia dalam hubungannya dengan masyarakat Indonesia di mana ia hidup melindungi dan mengembangkan martabat manusia dan turut memajukan kesejahteraan umum. Perlu ditanyakan pula apakah Gereja berhasil memanfaatkan situasi dan kekayaan budaya, sosial-ekonomi dan politik Indonesia untuk memahami lebih dalam imannya sendiri dan untuk mewartakannya. Di bawah ini akan diberikan beberapa contoh menurut sebagian bidang-bidang yang dipaparkan oleh GS.

Pada masa awal Orde Baru pemerintah lewat program KB berusaha menekan laju jumlah penduduk agar kesediaan pangan tetap cukup bagi rakyat. Menurut program ini keluarga yang ideal adalah keluarga yang hanya memiliki paling banyak dua anak. Untuk mencapai tujuan ini suami dan terutama istri "diharuskan" menggunakan alat-alat kontrasepsi. Bagaimana Gereja Indonesia harus bersikap? Dalam hal ini Gereja mengikuti apa yang diajarkan oleh GS. Gereja tetap melihat penerusan keturunan sebagai partisipasi manusia dalam karya penciptaan Allah. Dari lain pihak Gereja juga menyadari bahaya dari laju pertumbuhan penduduk yang tidak terkendali. Oleh karena itu Gereja Indonesia sesuai dengan ajaran GS menentang penggunaan alat-alat kontrasepsi 
yang menyebabkan pengguguran kandungan karena melanggar martabat dan hak asasi manusia akan hidup. Sedangkan menyangkut penggunaan alat-alat kontrasepsi yang mencegah terjadinya pertemuan sperma dan sel telur sejauh tidak membahayakan kesehatan pemakainya diserahkan kepada keputusan hati nurani masingmasing umat. Sikap Gereja Indonesia ini tidak sesuai dengan sikap Roma yang menentang secara absolut penggunaan alat-alat kontrasepsi.

Selanjutnya, menyangkut kehidupan berkeluarga ini, menurut hemat saya, yang perlu dicatat sebagai prestasi Gereja Indonesia adalah kursus persiapan perkawinan yang diselenggarakan oleh komisi keluarga di masing-masing keuskupan. Kursus perkawinan membantu pasangan-pasangan untuk melihat kedalaman arti duniawi dan imani kehidupan berkeluarga. Dengan demikian umat Katolik berpartisipasi dalam peneguhan hidup bersama.

Dalam bidang kebudayaan apa yang dilakukan oleh Pusat Musik Liturgi (PML), Yogyakarta mau tidak mau harus diacungi jempol. Menurut GS sebuah budaya sekaligus membantu kita mengalami iman kita sendiri dan dapat menjadi ungkapan dan sarana pewartaan iman. Tokoh-tokoh PML bersama senimanseniman di berbagai daerah di nusantara berproses menciptakan lagu-lagu liturgi-memakai istilah PML - bergaya budaya tertentu (Dayak, Jawa, Sunda, Nias, Tionghoa dan sebagainya). Misalnya saja mereka mendengarkan "nyanyian" (teriakan?) seorang dukun ketika menjalankan sebuah ritual dan mencatat notasinya. Notasi itu kemudian dipergunakan untuk menyusun lagu-lagu liturgi. Dengan demikian lirik yang berisi iman kristiani diungkapkan dan dialami dengan rasa tertentu, yang tidak asing bagi umat setempat. Dari sudut rasa iman tidak lagi menjadi sesuatu yang asing.

Usaha-usaha serius yang berbobot lainnya adalah arsitektur pada gereja-gereja yang dirancang oleh Rm. Mangunwijaya dan gereja di Pohsarang. Ibadat di Pohsarang pun dilakukan dalam bahasa Jawa dan diiringi dengan gamelan dan lagu-lagu berbahasa Jawa. Sebenarnya dulu di pelataran gereja Pohsarang terdapat amphiteatrum (stadion) kecil yang terbuka. Di situ biasa dipentaskan drama-drama Kitab Suci dalam bahasa Jawa. Amphiteatrum itu telah ditimbun, dan kalau tidak salah, sekarang menjelma menjadi tempat parkir. Sebuah dekadensi, kemerosotan budaya!
Gereja juga turut serta dalam pemunahan bahasa-bahasa daerah di Indonesia. Amat sangat sedikit Gereja yang merayakan Ibadat dan Ekaristi dalam bahasa daerah. Padahal sebuah bahasa akan punah atau, dengan kata lain, menjadi bahasa mati kalau ia tidak digunakan. Bila bahasa semakin sedikit jumlahnya, semakin miskinlah batin manusia.

Dalam bidang persekolahan amat menyedihkan melihat penutupan banyak sekolahsekolah Katolik yang justru bersentuhan dengan kalangan bawah di dalam masyarakat. Gereja tidak mampu lagi membiayai sekolah-sekolah tersebut.

Kegagalan yang lebih mengenaskan lagi dalam bidang budaya adalah kegagalan Gereja mengembangkan tata susila (moral) para anggotanya dan dengan demikian moralitas rakyat Indonesia. Ternyata orang-orang Katolik turut serta dalam tindakan suap dan korupsi. Daerah-daerah di mana umat Katolik atau Protestan menjadi mayoritas ternyata sama koruptifnya dengan daerah-daerah lain.

Dalam bidang ekonomi CU (Credit Union) yang dipelopori pembentukan dan pengorganisasiannya oleh Gereja Katolik, khususnya di Kalimantan Barat dan Sumatera Utara adalah kegiatan ekonomi yang secara cemerlang memenuhi apa yang dituntut oleh GS agar diciptakan ekonomi yang berkeadilan. Di Kalimantan Barat gedung-gedung kantor CU berdiri megah dan bahkan beberapa telah memiliki ATM. Kita tahu bahwa CU merupakan milik para anggotanya. Demikian pula laba yang diperoleh. CU telah secara nyata membantu banyak rakyat kecil memperbaiki kesejahteraan hidup mereka sehingga mereka menjadi otonom dan memiliki kepercayaan diri.

Gereja tidak berdaya, bahkan mungkin lebih tepat dikatakan bahwa Gereja nyaris tidak melakukan apa pun dalam mengupayakan keadilan ekonomi bagi generasi rakyat Indonesia di masa depan. Hutan-hutan di Indonesia nyaris tidak ada lagi. Semua telah diubah menjadi perkebunan monokultur, khususnya sawit. Tambang-tambang dikeruk tanpa memperhatikan faktor lingkungan hidup. Kita sedang menyediakan bumi yang tidak nyaman ditempati oleh generasi di masa depan.

Dalam kehidupan bernegara pada dasarnya umat Katolik berpartisipasi aktif mulai dari tingkat RT/RW sampai dengan tingkat nasional. Hanya saja moral umat Katolik dalam kehidupan 
bernegara tidak lebih baik daripada moral orang lain. Kehidupan khas beragama seperti misalnya ibadat ternyata tidak berpengaruh pada kehidupan nyata dalam bernegara dan bermasyarakat.

Karena pada dasarnya resepsi bukan hanya sekadar pembaharuan formal dan institusional, maka pada akhir pembahasan boleh ditanyakan apakah resepsi GS telah sampai pada tahap di mana GS menjadi kesadaran, mentalitas dan spiritualitas umat beriman Indonesia.

\section{PENUTUP}

Ada beberapa indikasi penting sebagai bentuk resepsi Gereja Indonesia terhadap GS. Pertama, penerjemahan dokumen Konsili Vatikan II ke dalam bahasa Indonesia yang dilakukan oleh Riberu dan diterbitkan pada tahun 1983 merupakan langkah penting untuk memperkenalkan dan menyampaikan ajaran Konsili Vatikan II. Penerbitan terjemahan ini terjadi delapan belas tahun setelah Konsili Vatikan II. Meskipun bisa dikatakan sangat lamban, setelah menunggu 18 tahun akhirnya institusi Gereja Indonesia, dalam hal ini KWI, membuat langkah penting untuk memperkenalkan ajaran Konsili Vatikan II, termasuk didalamnya adalah GS. Terjemahan ini berhasil diperbarui oleh R. Hardawirjana pada tahun 1993.

Kedua, upaya kedua yang berciri kerugmatik untuk mensosialisasikan GS dibuat oleh Tom Jakobs. Jakobs berhasil menyampaikan pemikiran Konsili Vatikan II dalam berbagai karya ilmiah berupa buku dan artikel. Tidak banyak teolog lain yang memberi perhatian khusus pada upaya menyampaikan ajaran Konsili secara ilmiah dan terpublikasi.

Ketiga, pengajaran pokok-pokok ajaran Konsili Vatikan II dalam berbagai sekolah Filsafat dan Teologi di Indonesia memberi peran penting dalam memperkenalan GS kepada para pemimpin Gereja. Porsi pengajaran masih terkesan minim.

Keempat, KWI melalui Komisi Kateketik menerbitkan buku Iman Katolik sebagai katekismus yang didasarkan pada Konsili Vatikan II dengan tetap memperhatikan situasi khusus di Indonesia.

Kelima, penerimaan GS juga terlihat dalam Sidang Agung (SAGKI) pada tahun 2000, 2005, dan 2010 yang mengikutsertakan perwakilanperwakilan awam. Dengan demikian, anggota umat Allah benar-benar dilibatkan.

\section{Laurensius Sutadi}

Dosen Pascasarjana STFT Pastor Bonus Pontianak Kalimantan Barat; Alumnus Program Doktoral Teologi Universitas Urbaniana, Roma: derabad@yahoo.com

\section{CATATAN AKHIR}

1 Dalam Bahasa Indonesia dan Inggris resepsi juga memiliki arti sebuah pesta yang disertai dengan jamuan makan.

2 Kenneth R. Hmes, "Mixed Reaction: The Reception of Gaudium et Spes", 10.

3 Bdk. H. Jedin, Sejarah Konsili, terj. Dick Hartoko, 137138.

4 G. Routhier, La reception d' un concile, 69. Dalam membahas resepsi konsili kita akan mengikuti pemikiran G. Routhier.

5 Selanjutnya disingkat GS

6 Bdk. Giuseppe Alberigo, History of Vatican II, Vol. 1, 60-91

7 Vatikan II berlangsung dalam 4 sesi: Sesi I (11 Oktober - 8 Desember 1962), Sesi II (29 September - 4 Desember 1963), Sesi III (14 September-21 November 1964) dan Sesi IV (14 September-8 Desember 1965). Alan Schreck, Vatican II: The Crsisis and the Promise, 62-63.

8 Tanggapan lengkap Kardinal Suenens dapat dibaca di Tom Jacobs, Latar Belakang Gaudium et Spes, 1-5.

9 Bdk. Giuseppe Alberigo, History of Vatican II, Vol.3, 53-54.

10 Bdk. Tom Jacobs, "Gereja dan Dunia" dalam JB. Banawiratma, Gereja dan Masyarakat, 19-21.

11 Xavier Rynne, Vatican Council II, 45-48

12 Tom Jacobs, Latar Belakang Gaudium et Spes, 40-47.

13 Bdk. GS 4

14 Tom Jacobs, Latar Belakang Gaudium et Spes, 40-47.

15 Ibid., hal. 42.

16 KWI, Iman Katolik, Xi.

\section{DAFTAR PUSTAKA}

Allan Schreck, 2005. Vatikan II: The Crisis and The Promise, Servant Books, Cincinati.

Giusseppe Alberigo, 1993. History of Vatikan II, Vol. 1, Orbis, Maryknol.

Giusseppe Alberigo, 1993. History of Vatikan II, Vol. 3, Orbis, Maryknol.

H. Jedin, 1973. Sejarah Konsili, Kanisius, Yogyakarta. 
Kennet R. Himes, 1990. "Mixed Reaction: The Reception of Gaudium et Spes", dalam New Theology Review vol. 3 no. 01.

KWI, 1996. Iman Katolik, Kanisius, Yogyakarta.

Tom Jacobs, "Gereja dan Dunia", dalam JB.

Banawiratma, Gereja Dan Masyarakat, Kanisius, Yogyakarta.
Tom Jacobs, 2002. Latar Belakang Konsili Vatikan II, Celesty Hieronika, Jakarta.

Xavier Rynne,1999. Vatican Council II, Orbis Books, New York. 